\title{
The Impact of Selected Biotechnology Processes for Sustainable Development of the Environment and Human Life
}

\section{Wpływ wybranych procesów biotechnologicznych na zrównoważony rozwój środowiska i życie człowieka}

\author{
Aleksandra Badora, Magdalena Celińska \\ Department of Agricultural and Environmental Chemistry, \\ University of Life Sciences in Lublin, Akademicka 15 Street, 20-950 Lublin, Poland \\ E-mail (corresponding author): aleksandra.badora@up.lublin.pl
}

\begin{abstract}
The aim of this work was to show what effect biotechnology can have on the quality of human life, and on the condition of the natural environment. A number of biotechnological processes have been analyzed that can significantly improve the quality of human life, while at the same time caring for the natural environment. The prospects for the development of these processes on the global and Polish market were also analyzed. As it turned out, some of the process analyzed need further refinement to be implemented on a global scale, while others may be successfully implemented in the coming years, contributing to the improvement of the quality of such aspects of human life high-quality food products, health protection and good public health. Biotechnological processes may also have wide application in the protection and remediation of the natural environment.
\end{abstract}

Key words: biotechnology, human life, environmental protection, GMO

\section{Streszczenie}

Celem niniejszej pracy było wykazanie, jaki wpływ może mieć biotechnologia na jakość ludzkiego życia, oraz na stan środowiska naturalnego. Przeanalizowano szereg procesów biotechnologicznych, mogących w znaczący sposób poprawić jakość życia człowieka, z jednoczesną dbałością o środowisko naturalne. Przeanalizowano również perspektywy rozwoju tychże procesów na rynku światowym oraz polskim. Jak się okazało, niektóre z tych procesów wymagają dalszego dopracowania, by można je wdrażać na skalę światową, natomiast inne mogą z powodzeniem, w ciągu najbliższych lat, zostać wprowadzone w celu lepszego dostępu do produktów spożywczych wysokiej jakości oraz zachowanie społeczeństwa w dobrej kondycji zdrowotnej. Procesy biotechnologiczne mogą również mieć szerokie zastosowanie w ochronie iremediacji środowiska naturalnego.

Słowa kluczowe: biotechnologia, życie człowieka, ochrona środowiska, GMO

\section{Introduction}

In recent years, the world's population has grown and now stands at 7.433 billion (Fundusz Ludnościowy Narodów Zjednoczonych, 2016). Along with the increase in the population, the needs of the society are also growing, especially in the areas of health protection, consumption, education, improvement of the quality of life and its standards. There are new chal- lenges that force continuous development and search for effective methods of improving life on earth. Civilization progress also entails dangers, such as developing civilization diseases and threats caused by environmental contamination. The growing human population needs to provide high-quality food, clean water, access to effective medicines, as well as guarantee safety and maintain a high standard of living. All these factors force the development of many 
branches of science, including biotechnology, which will eliminate or minimize the negative effects of global civilization development and face new challenges (Dorocki and Jastrzębski, 2012).

The growing awareness and level of knowledge and available technology make it possible that the problems that were once unresolvable can be overcome, among others thanks to the development of science such as biotechnology. It is an interdisciplinary field combining techniques and knowledge of many exact sciences, including biology, including genetic engineering, chemistry and physics. It means a technological application that uses biological systems, living organisms, their parts or products to manufacture or modify raw materials, finished products and processes for a specific purpose on an industrial scale (Przybecki et al., 2010, Betyna, 2017). The dynamic development of biotechnology is now visible in many areas of life, and has a significant impact on the environment in which we live (Przybecki et al., 2010).

The aim of this work was, therefore, to analyze the possibilities of improving the quality of human life as well as the state of the natural environment that results from the development of biotechnology. The following research hypotheses were put forward in this analysis:

- Biotechnology will be increasingly used in agricultural production and cultivation of GMO crops as well as in the food economy.

- Biotechnology processes using microorganisms can be used in cleaning the environment from organic pollutants.

\section{Environmental protection}

The dynamic development of civilization in recent years and the growing awareness of protection and care for the natural environment, recently contribute to the development of branches of bioengineering, which would enable the implementation of the socalled sustainable development, which would provide all the needs of society, while keeping in mind the welfare of the natural environment and other living organisms, not just people (Skowroński, 2006). The progress of civilization itself contributes to the creation of many new threats that the environment did not have before. There are more and more pollutants, more and more areas are being degraded or irreversibly devastated (Skowroński, 2006). It requires people, as beings responsible for this state of affairs, to react adequately to prevent further devastation or repair the effects of damage already done. Thanks to the development of modern biotechnology, the idea of sustainable development seems closer than ever (Skowroński, 2006; Poskrobko, 2011). This chapter will present selected techniques that can improve the quality of our environment and contribute to the reclamation of its already damaged part.

\subsection{Nano-technology in environmental protection} Recent changes in nanotechnology have helped to test carbon nanotubes (CNTs) as one of the beststudied nanomaterials. Utilizing the advantages of the extraordinary physical, chemical and electronic properties of CNT, a wide range of applications in various fields of engineering and environmental protection was proposed, such as: wastewater treatment, monitoring of air pollution, production of green energy (Hwang et al., 2007a, b; Onget al., 2010).

\section{Carbon nanotubes in wastewater treatment}

Wastewater discharges from domestic, industrial or agricultural sources cover a wide range of pollutants and raise serious concerns around the world as they have a negative impact on water quality. Impurities in wastewater, such as heavy metal ions, 1,2-dichlorobenzene and dioxins (they are irrelevant, highly toxic and carcinogenic) can result in accumulative poisoning, cancer and nervous system damage (Baillie et al., 2004; Dalton et al., 2004; Fagan et al., 2007). The removal of these impurities depends on the sorptive properties of the CNT sorbent, due to the high surface to volume ratio and controlled pore size distribution, they have exceptional sorption capacity and high sorption performance compared to conventional granulated and pulverized activated carbon that has internal constraints such as sites surface active and sorption activation energy (Ong et al., 2010). These properties of high sorptive potential can therefore be used to purify waste water from organic and inorganic contaminants and as nanofilters to reduce particle concentrations in wastewater (Srivastava et al., 2004; Ong et al., 2010).

However, the use of CNT in wastewater treatment is not limited to filtration and sorbent; several scientists (Endo et al., 2008, Kang et al., 2008, Cortes et al., 2009) have observed the strong antimicrobial properties of CNT. This behavior allows the CNT to replace chemical disinfectants as a new effective way to control pathogenic microorganisms (Kang et al., 2008). The use of CNT in the water disinfection process avoids the formation of harmful disinfection byproducts (DBPs), such as trihalomethanes, haloacetic acids and aldehydes, because they are not strong oxidants and are relatively inert in water (Savage and Diallo, 2005; Mostafavi and Shamspur, 2009 ). Highly purified CNTs exhibit strong antimicrobial activity against Gram-positive and Gram-negative bacteria as well as their spores (Ong et al., 2010).

\section{CNT in air pollution}

The properties of carbon nanotubes allowed them to be used as elements to detect and monitor the concentration of toxic gases released in the environment. Detection by this gas sensor is based on changes in resistance or conductivity in the CNT as a result of direct contact with gas. CNT based gas sensors have many advantages over conventional semiconductor oxide gas sensors, such as low energy consumption, 
low operating temperature and high sensitivity (Ong et al., 2010).

\section{Carbon-based nanocomposites}

Waste generation is proportional to global economic growth (Ong et al., 2010). Waste, especially synthetic polymer waste, has a negative impact on the environment. Therefore, to address this problem, the European Community proposed a waste management concept based on two complementary strategies: avoiding waste through improved product design and increased waste recycling and reuse, with an emphasis on life cycle assessment (LCA) to generate a transparent and a complete environmental impact assessment resulting from all stages of the life cycle of a given product or activity and using it to assess its environmental characteristics (Baillie, 2004; Ong et al., 2010).

Future prospects for solving waste disposal problems posed a challenge to the synthesis of green nanocomposites through the use of biodegradable polymers in the context of a new generation of wave materials (Wang et al., 2005; Dhillon et al., 2018). The green nanocomposite trend, which uses natural renewable resources, includes the LCA concept that promotes recycling and re-use of waste. Biodegradable polymers have great potential commercial value and arouse great interest of scientists as an alternative to replace non-renewable petroleum based polymers due to their susceptibility to decomposition. However, most biodegradable polymers have poorer mechanical properties and a low temperature of thermal strain, which limits their use in a wide range of applications. Therefore, CNT nanoparticles can act as a reinforcement for biodegradable polymers to provide a set of composite materials with improved mechanical properties, greater durability and better thermal stability (Ong et al., 2010).

Another advantage offered by green nanocomposites is the possibility of recycling the introduced CNTs due to the susceptibility to biodegradable polymer degradation (Savage and Diallo, 2005). The degradation of the biodegradable polymer can be achieved by microbial degradation or enzymatic degradation under specific $\mathrm{pH}$ and temperature conditions (Savage and Diallo, 2005). After degradation, recovered CNTs can act as a reinforcing filler for the production of new composites. Reuse and recycling CNT can reduce landfilling while being cost-effective in terms of material processing (Ong et al., 2010).

\section{Bioengineering of microorganisms in environmental remediation}

Methane is an important greenhouse gas produced from many natural and anthropogenic sources. It plays an important role in general global warming (Kundzewicz and Juda-Rezler, 2010). A significant amount of methane is removed through microbial oxidation by methanotrophic bacteria, which are widespread in the environment, including many ex- treme environments. The key enzyme of these microorganisms, methane monooxygenase (MMO), especially soluble MMO, is distinguished by its wide substrate specificity (Wójcik and Tomaszewska, 2005). This unique ability, i.e. the catalysing of environmental responses, has attracted the attention of microbiologists and biochemical engineers. In recent years, significant advances have been observed in the use of methanotrophs for environmental remediation. They are used in methane removal and biodegradation of toxic compounds (Wójcik and Tomaszewska, 2005). The removal of methane produced on landfills has been extensively studied, and the results indicate that micro-organisms can be used to remove mine gas.

In recent years, many bioreactors have been developed that use methanotrophs for bioremediation (Smith et al., 1997, Ferrai et al., 2010). Another application for microorganisms in the bioremediation of the environment is its purification from PAHs (polycyclic aromatic hydrocarbons) (Wójcik and Tomaszewska, 2005, Waraczewska et al., 2018). There are used special strains, among others from the genus Pseudomonas, Arthrobacter, Alcaligenes, Corynebacterium (Wójcik and Tomaszewska, 2005). When the efficiency of natural bioremediation is not satisfactory, bioremediation supported by biogenic elements is used. Bioremediation of this type is applied to soils contaminated with fossil fuels and to waters, mainly groundwater (Waraczewska et al., 2018).

\section{Bioremediation supported by ultrasounds}

Recent tests have shown that ultrasound can be used in many remediation techniques, i.e. decomposition or degradation of sewage sludge, improvement of drinking water quality or purification of used water (Wang et al., 2010). The above data is presented in Table 1 .

Table 1. Application of ultrasounds in environmental engineering in selected aspects (Wang et al., 2010).

\begin{tabular}{|l|l|}
\hline The purpose of the impact & Action \\
\hline Drinking water & $\begin{array}{l}\text { Inactivation of harmful } \\
\text { microorganisms, separa- } \\
\text { tion of solid bodies, re- } \\
\text { moval of incrustations in } \\
\text { water pipes and wells }\end{array}$ \\
\hline Used water & $\begin{array}{l}\text { Degradation of pollutants, } \\
\text { improvement of biologi- } \\
\text { cal degradation, disinte- } \\
\text { gration of solids }\end{array}$ \\
\hline Sewage sludge & $\begin{array}{l}\text { Improvement of drainage, } \\
\text { decomposition of sludge } \\
\text { flakes to allow sedimenta- } \\
\text { tion }\end{array}$ \\
\hline
\end{tabular}

Advantages and limitations of using ultrasound The use of ultrasound improves the effectiveness of biological remediation. It is relatively cheaper than chemic or physical purification. Its use, however, has limitations. It cannot be used with a biological 
Table 2. Effectiveness of natural bioremediation and stimulated with hydrogen peroxide (Waraczewska et al., 2018).

\begin{tabular}{|c|c|c|c|c|}
\hline Type of bioremediation & Duration & The purified phase & $\begin{array}{c}\text { \% Removal of } \\
\text { xenobiotics }\end{array}$ & The type of xenobiotics \\
\hline \multirow{2}{*}{ Natural } & \multirow{2}{*}{90 days } & Soil & $57 \%$ & PAHs \\
\cline { 3 - 5 } & \multirow{2}{*}{ Stymulowana $\mathrm{H}_{2} \mathrm{O}_{2}$} & Groundwater & $99 \%$ & PAHs \\
\hline \multirow{2}{*}{60 days } & Soil & $81 \%$ & PAHs \\
\cline { 3 - 5 } & & Groundwater & $99 \%$ & PAHs \\
\hline
\end{tabular}

method to treat wastewater or water that contain bacteriotoxic compounds. It cannot be cleaned in this way also when microorganisms are not able to spread the pollutants themselves, because the ultrasounds only support their work, they are not able to make the bacteria break down the relationship when they cannot. These factors are most often found in industrial wastewater (Wang et al., 2010).

\section{Stabilization of slopes prone to erosion}

In recent years, to stabilize the soil easily undergoing erosion, higher plants with a properly selected root system are used. The root system of these plants serves as the basic structural element, stabilizing the soil. Thanks to this solution, the use of other artificial stabilizing materials is unnecessary, and hence, it is a much more natural process (Robertson and Samy, 2015; Morgan and Rickson, 2003). Various types of plants are used for this purpose, among others: forsythia (Forsythia ssp.), Rose (Rosa L.) and many others. Vegetable stabilizers are much cheaper and more durable than synthetic stabilizers. This solution is widely used in the United States to protect the slopes from erosion (Gray and Sotir, 1996, Morgan and Rickson, 2003).

\subsection{Biotechnology in environmental remediation}

\section{Effectiveness of bioremediation}

Thanks to advances in biotechnology, bioremediation has become one of the fastest growing areas of environmental renewal, using microorganisms to reduce the concentration and toxicity of various chemical pollutants, such as: petroleum hydrocarbons, polycyclic aromatic hydrocarbons, polychlorinated phenols, phthalate esters, nitroaromatic compounds, solvents dust, pesticides and heavy metals (Dua et al., 2002). Many bioremediation strategies have been developed to utilize contaminated waste and clean up degraded areas. The choice of the most effective remedy strategy for a particular contamination at a given time is done taking into account three basic principles:

- Possibility of biological transformation of pollutants into less toxic products.

- Availability of contaminants for microorganisms in the treated area.
- The possibility of optimizing the biological activity of the data of microorganisms.

In the case when the effectiveness of native microorganisms occurring in a given environment does not allow a satisfactory degree of decomposition of a given xenobiotic, so-called biostimulation. It is a method of providing microorganisms with large amounts of organic substances, in order to stimulate them to multiply biomass and faster xenobiotic distribution (Waraczewska et al., 2018). This paper compares the effectiveness of natural bioremediation and stimulated bioremediation. Data on this subject is presented in Table 2 .

As you can see, the degree of purification of both water and soil is high in both cases, however, bioremediation stimulated in the case of soil cleaning is much more effective than natural bioremediation. Both methods are therefore suitable for the purification of polluted PAH from petroleum. In turn, other authors (Robertson and Samy, 2015) have shown that the addition of elements such as activated carbon can further improve the effectiveness of assisted bioremediation.

The effect of the addition of elements such as nitrogen and phosphorus was also investigated. To study the effectiveness of particular types of bioremediation, the following bioreactors were created ( 2 for each trial) (Waraczewska et al., 2018):

- Natural bioremediation,

- Biostimulation with oxygen, nitrogen, phosphorus and carbon,

- Bioaugmentation with Pseudomonas aeruginosa and Bacillus subtilis strains,

- Bioaugmentation with Pseudomonas aeruginosa and Bacillus subtilis strains stimulated with the addition of nitrogen, phosphorus, oxygen and carbon.

The bioremediation process lasted 60 days. The effectiveness of individual variants is presented in Table 3 .

The study showed that the most effective method is bioaugmentation using specialized Pseudomonas aeruginosa and Bacillus subtilis strains additionally stimulated by biogenic elements (Waraczewska et al., 2018). These methods, like natural bioremediation, can be successfully used in cleaning and protecting the environment. 
Table 3. Effectiveness of various types of bioremediation (Waraczewska et al., 2018).

\begin{tabular}{|l|l|l|}
\hline Type of bioremediation & $\begin{array}{l}\text { Effec- } \\
\text { tiveness } \\
{[\%]}\end{array}$ & $\begin{array}{l}\text { Dura- } \\
\text { tion }\end{array}$ \\
\hline Natural bioremediation & $51,40 \%$ & $\begin{array}{l}60 \\
\text { days }\end{array}$ \\
\hline $\begin{array}{l}\text { Bioaugmentation with Pseudomo- } \\
\text { nas aeruginosa and Bacillus subtilis } \\
\text { strains }\end{array}$ & $62,90 \%$ & $\begin{array}{l}60 \\
\text { days }\end{array}$ \\
\hline $\begin{array}{l}\text { Biostimulation with oxygen, nitro- } \\
\text { gen, phosphorus and carbon }\end{array}$ & $81,90 \%$ & $\begin{array}{l}60 \\
\text { days }\end{array}$ \\
\hline $\begin{array}{l}\text { Bioaugmentation with Pseudomo- } \\
\text { nas aeruginosa and Bacillus subtilis } \\
\text { stimulated with the addition of nitro- } \\
\text { gen, phosphorus, oxygen and carbon }\end{array}$ & $89,7 \%$ & $\begin{array}{l}60 \\
\text { days }\end{array}$ \\
\hline
\end{tabular}

\section{Food industry and human nutrition}

Trends in the development of GMO crops

In recent years, a decrease in the area of GMO crops has been observed in many European countries (Chorąży and Lisowska, 2011). This may result in an increase in food prices obtained from GMO crops, and the long-term persistence of a low share of GMO crops in agriculture can completely eliminate transgenic plants as a food source. The current food trends and consumer preferences are also conducive to this. Contemporary consumers prefer foods certified with GMO-free (Gębski and Kosicka-Gębska, 2008). Trends in the development of GMO-based agriculture are presented in Table 4. As can be seen, in most European countries in the years 2008-2010 a decrease in the cultivated area was observed. The biggest decrease was in Germany, the smallest one in Poland, where the area of GMO cultivation remained stable. Sweden and Portugal were the only countries with a positive growth rate. This may suggest that the interest in growing GMO crops is not constant over the years and may be subject to periodic fluctuations. Other authors (James, 2010, NiemrowiczSzczytt et al., 2012) report that currently the area of GMO crop cultivation in the world (excluding the EU) is constantly growing.

The impact on the selection of a crop (transgenic or not) can have many factors, such as the availability of transgenic seeds in the market or the profitability of the crop. Also, the policies of states, including EU member states, and all restrictions on cultivation and trade in GM varieties, may discourage (or encourage) farmers to use transgenic varieties. Another important factor is also the mentioned food preferences of consumers. If we could convince the public that genetically modified plants are completely safe and have improved values, GMO plant production could turn out to be more profitable and their market price would significantly decrease with their availability, and the increased demand for products from them received.
Plants genetically modified in food production

Every year there are reports of receiving new transgenic plants (James, 2010, Niemrowicz-Szczytt et al., 2012). However, only a few species and several features introduced to them have registered varieties and are grown on a larger scale (Niemrowicz-Szczytt et al., 2012). According to data published by ISAAA (International Service for the Acquisition of Agri-biotech Applications) (James, 2010, NiemrowiczSzczytt et al., 2012), in total around 148 million ha of genetically modified plants were cultivated in 2010, including 17 countries in the world, the area of cultivation exceeded 50,000 ha. Individual plants, along with the country of their cultivation, are presented in Table 5.

The area of cultivation of GMO plants is constantly growing. Their cultivation is demonstrated in 29 countries around the world (Niemrowicz-Szczytt et al., 2012). Most of these plants are grown in the USA-66.8 million ha. The next largest country is Brazil (25.4 million ha), followed by Argentina (22.9 million ha), India (9.4 million ha) and Canada (8.8 million ha). The largest area of GMO cultivation is soy (about $50 \%$ ), followed by maize (about $31 \%$ ), cotton (about 14\%) and rapeseed (about 5\%) (James, 2010). At present, these are GMO species that are the most commonly cultivated (Niemrowicz-Szczytt et al. 2012). In addition to the four mentioned species, there are others that are grown on a smaller scale or only introduced in certain countries. These include potato (Czech Republic, Sweden and Germany), sugar beet (USA and Canada), papaya (USA and China), alfalfa and pumpkin (USA), paprika, tomato and poplar (China) (James, 2010). Lucerne GMO has been introduced to cultivation in the US since 2011.

The most varieties have introduced herbicide resistance genes (about $61 \%$ of the crop area), then with double or triple resistance (herbicides and insects - about 22\%) and insects themselves (about 17\%) (Niemrowicz-Szczytt et al. , 2012). Proponents of the modification argue that genetically modified plants show greater resistance to adverse environmental conditions, as well as to viruses and fungi, which allows reducing the amount of chemicals used, and thus potentially less contamination of the natural environment (Niemrowicz-Szczytt et al., 2012). Transgenic plants with various introduced genes have been obtained in many centers in the world (Niemrowicz-Szczytt et al., 2012). However, they do not appear on the market because they do not guarantee high income. It has long been announced that the Golden Rice market will be introduced with increased content of provitamin A and soybeans with an increased content of omega- 3 fatty acids, as well as species of economically important plants with increased tolerance to drought (Ansell and McGin, 2009). 
Table 4. Area (ha) of GMO crops in Europe in 2008-2010 (Chorąży and Lisowska, 2011).

\begin{tabular}{|c|c|c|c|c|}
\hline Country & 2008 & 2009 & 2010 & Change (\%) \\
\hline Spain & 79269 & 76057 & 67726 & -15 \\
\hline Portugal & 4856 & 5202 & 4869 & 0,3 \\
\hline Romania & 6130 & 3244 & 823 & -87 \\
\hline Germany & 3173 & 30 & 28 & -99 \\
\hline Czech Republic & 8380 & 6480 & 4830 & -42 \\
\hline Slovakia & 1931 & 875 & 875 & -55 \\
\hline Poland & 3000 & 3000 & 3000 & 0 \\
\hline Sweden & 0 & 0 & 103 & 100 \\
\hline Overall I'd & 106739 & 94888 & 82254 & -23 \\
\hline
\end{tabular}

Table 5. Area of GMO crops cultivation in individual countries (James, 2010, Niemrowicz-Szczytt et al., 2012).

\begin{tabular}{|c|c|c|c|}
\hline Lp. & Country & Surface (mln ha) & A species of transgenic plant \\
\hline 1. & USA & 66,8 & Corn, soybean, cotton, rape, beetroot, alfalfa, papaya, pumpkin \\
\hline 2. & Canada & 8,8 & Rape, maize, soybeans, sugar beet \\
\hline 3. & Mexico & 0,1 & Cotton, soy \\
\hline 4. & Brazil & 25,4 & Soy, corn, cotton \\
\hline 5. & Argentina & 22,9 & Soy, corn, cotton \\
\hline 6. & Chile & $<0,1$ & Soy, maize, rape \\
\hline 7. & Honduras & $<0,1$ & Maize \\
\hline 8. & Costa Rica & $<0,1$ & Cotton, soy \\
\hline 9. & Columbia & $<0,1$ & Cotton \\
\hline 10. & Philippines & 0,5 & maize \\
\hline 11. & Bolivia & 0.9 & Soy \\
\hline 12. & Uruguay & 1,1 & Soy, corn \\
\hline 13. & Paraguay & 2,6 & Soy \\
\hline 14. & Portugal & $<0,1$ & Maize \\
\hline 15. & Spain & 0,1 & Maize \\
\hline 16. & Czech Republic & $<0,1$ & Corn, potato \\
\hline 17. & Slovakia & $<0,1$ & Maize \\
\hline 18. & Poland & $<0,1$ & Maize \\
\hline 19. & Germany & $<0,1$ & Potato \\
\hline 20. & Romania & $<0,1$ & Maize \\
\hline 21. & Sweden & $<0,1$ & Potato \\
\hline 22. & Egypt & $<0,1$ & Maize \\
\hline 23. & South Africa & 2,2 & Corn, soy, cotton \\
\hline 24. & Burkina Faso & 0,3 & Cotton \\
\hline 25. & Myanmar & 0,3 & Cotton \\
\hline 26. & Australia & 0,7 & Cotton, rape \\
\hline 27. & China & 3,5 & Cotton, papaya, poplar, tomato, sweet pepper \\
\hline 28. & Pakistan & 2,4 & Cotton \\
\hline 29. & India & 9,4 & Cotton \\
\hline \multicolumn{2}{|r|}{ Summary } & 148 & - \\
\hline
\end{tabular}


New technologies related to GMO contributed to the development of food control methods (Malepszy, 2006; Malepszy et al., 2009). Establishment of a network of reference laboratories allows the state to control and assess the risk of GMO imported to a given country (Niemrowicz-Szczytt et al., 2012).

\section{GMOs in Polish agriculture}

Poland as an angricultural country is an interesting example. In Poland there is a ban on the GMO seed trade, but there is no ban on agricultural production. The cultivation of genetically modified plants is therefore legal (Twardowski and Węgleński, 2012). In 2008, about 3,000 hectares of Bt maize were grown in Poland, but it should be emphasized that these are estimates, because in Poland there is currently no obligation to register GM crops (Twardowski and Węgleński, 2012). It can be assumed that the Bt corn cultivation area is much larger. The seed is imported from neighboring countries. From March 2010, agricultural production of Amflora potato is possible in European Union countries. Potato Amflora GMO (registered by the EU on March 2, 2010) - is an industrial variety, starchy, which produces amylose to a small extent, and biosynthesizes almost exclusively amylopectin. This variety is not suitable for consumption. The issue of the production of industrial feeds is now a key issue for Poland. The basis for the production of fodder necessary for the production of meat (poultry, beef and pork), milk and eggs and all derived products is soybean meal, produced from GMO soybeans after extrusion of oil. Soybean meal is imported by Poland in the amount of approx. 2 million tons per year, mainly from South America. About $98 \%$ of this meal comes from GMO soy, which is about 20-30\% cheaper than unmodified (non-GMO). It should be noted that the attempt to purchase 2 million tonnes of non-GMO soy in the global market would increase the price of such a product. Soybean meal is widely used as fodder on poultry farms (Twardowski and Węgleński, 2012). 5052 farms produce poultry, employ 15,000 people and 40,000 seasonal workers. The ban on the use of GMO feeds threatens the bankruptcy of $1 / 3$ of farms and poultry plants, especially smaller companies, and first of all family enterprises. According to estimates of the National Research Institute of Animal Production (PIB), the following social effects should be expected (Twardowski and Węgleński, 2012, Gębski and Kosicka-Gębska, 2014):

- Decrease in the production of poultry meat and the resulting increase in its price and derivatives,

- Decrease in consumption of poultry meat by $30-50 \%$,

- Increased family maintenance costs,

- Limiting the consumption of meat will affect the poorest families,
- $\quad$ The need to import meat and uncertainty as to its quality,

- High import costs,

- Restriction of the poultry production sector.

\section{Conclusions}

Biotechnology, understood as genetic recombination of plants, is less and less used in most EU countries, due to legal restrictions and consumer reluctance to buy products from modified plants, while interest in transgenic plants increases in countries where domestic policy is not so restrictive, and where there are nutritional trends, prompting people to buy products from GMO plants.

Food and other products obtained from GMO have been fully accepted in the USA, Canada, Brazil and other countries. In Europe, there is a reluctant or hostile attitude towards them. This is primarily due to the fact that Europe is in terms of using new technologies in agriculture lagging behind the United States and wants to stop the flow of cheaper food and feed from the USA. Reluctance to GMOs means that legal regulations in this area are much more restrictive in the European Union than in other countries. Unfortunately, the shape of draft GMO laws developed in Poland shows that the proposed provisions will be even more restrictive than the EU legal requirements.

Specialists indicate that in the future abandoning agrobiotechnology can lead to a significant increase in food prices. In countries not using biotechnology in agriculture, there would be a rapid decline in the quality of life in relation to countries that use it skillfully. A particularly important case is the further development of Polish agriculture, where it is necessary to take into account such factors as: fragmentation of arable land and the social role of small-scale farms and organic production in comparison with the importance of large-scale agricultural production.

As it turned out, bioremediation based on live microorganisms is a very effective method, allowing the neutralization of a large amount of organic pollutants, and thus can be successfully used to improve the condition of the natural environment.

\section{References}

1. ANSELL E., MCGINN E., 2009, GM stockfeed in Australia: economic issues for producers and consumer, Research report prepared for the Australian Government Department of Agriculture, Fisheris and Forestry, Canberra, https://www.australianstockrepor t.com.au/asx-build-wealth?campaignid.

2. BAILLIE C. A., BARBER A. H., ZHAO Q., WAGNER H. D., 2004, Characterization of E-glass-polypropylene interfaces using carbon nanotubes as strain sensors, in: Composites Science and Technology, 64(13-14), p. 1915-1919. 
3. BETYNA M., 2017, Bioengineering in cosmetology - the overview of present state and future prospects, in: World Scientific News, 89, 199-207.

4. CHORĄŻY M., LISOWSKA K., 2011, Dlaczego mówimy nie dla GMO w polskim rolnictwie, in: $\mathrm{Na}$ $u k a, 4,175-180$.

5. CORTES P., DENG S., SMITH G. B., 2009, The adsorption properties of bacillus atrophaeus spores on single-wall carbon nanotubes, in: Journal of Sensors, article no 131628.

6. DALTON A. B., MUÑOZ E., COLLINS S., KOZLOV M., RAZAL J., COLEMAN J. N., KIM B. G., EBRON V. H., SELVIDGE M., FERRARIS J. P., BAUGHMAN R. H., 2004, Multifunctional Carbon Nanotube Composite Fibers, in: Journal Composite Materials, 44(11), p. 1305-1316.

7. DHILLON A., PAINULI R., KUMAR D., 2018, Carbon Nanostructures: Applications and Perspectives for a Green Future, in: Nanocomposites for Pollution Control, p. 249-285, Pan Stanford.

8. DOROCKI S., JASTRZĘBSKI J., 2012, Regionalne zróżnicowanie rozwoju biotechnologii w Europie, in: Prace Komisji Geografii Przemystu Polskiego Towarzystwa Geograficznego, 20, p. 67-94.

9. DUA M., SINGH A., SETHUNATHAN N., JOHRI A., 2002, Biotechnology and bioremediation: successes and limitations, in: Applied Microbiology and Biotechnology, 59(2-3), p. 143-152.

10. ENDO M., NATSUKI T., Q. Q. NI, 2008, Analysis of the vibration characteristics of double-walled carbon nanotubes, in: Carbon, 46(12), p. 1570-1573.

11. FAGAN J., KASIGAWI T., DOUGLAS J. F., YAMAMOTO K., HECKERT A. N., LEIGH S. D., OBRZUT J., DU F., LIN-GIBSON S., MU M., WINEY K. I., HAGGENMULLER R., 2007, Relationship between dispersion metric and properties of PMMA/ SWNT nanocomposites, in: Polymer, 48(16), 48554866.

12. FERRAI M., GUGLIELMI G., ANDREOTTOLA G., 2010, Modelling respirometric tests for the assessment of kinetic and stoichiometric parameters on MBBR biofilm for municipal wastewater treatment, in: Environmental Modelling \& Software, 25(5), p. 626-632.

13. FUNDUSZ LUDNOŚCIOWY NARODÓW ZJEDNOCZONYCH, 2016, Report from the day December 1, 2016.

14. GĘBSKI J., KOSICKA-GĘBSKA M., 2014, Wpływ wyróżników jakości na zachowania konsumentów mięsa, in: Roczniki Naukowe Stowarzyszenia Ekonomistów Rolnictwa i Agrobiznesu, 16(1), p. 98-104.

15. GRAY D. H., SOTIR R. B., 1996, Biotechnical and soil bioengineering slope stabilization: a practical guide for erosion control, John Wiley \& Sons.

16. HWANG S. W., ZACHARIA R., RATHER S., NAHM K. S., 2007a, Spillover of physisorbed hydrogen from sputter-deposited arrays of platinum nanoparticles to multi-walled carbon nanotubes, in: Chemical Physics Letters, 434(4-6), p. 286-291.

17. HWANG S. K., JIN H, KWON J. T., CHANG S. H., KIM T. H., CHO C. S., LEE K. H., YOUNG M. R., COLBURN N. H., BECK JR G. R., YANG H. S., CHO M. H., 2007b, Aerosol-delivered programmed cell death 4 enhanced apoptosis, controlled cell cycle and suppressed AP-1 activity in the lungs of AP-1 luciferase reporter mice, in: Gene Therapy, 14; p. $1353-1361$
18. JAMES C., 2010, Global status of commercialized Biotech/ GM Crops, in: ISAAA Brief, 42. ISAAA, Ithaca, NY

19. JORDAN E., MARTIN J., HILMY HAKEEM M., SURYAJAYA T., NUGRAHA T., TAUFIQURRAHMI LISTYORIN N., 2016, A review of nanotechnology application for seawater desalination proces, in: Journal of Technology, Maret, 1(2), p. 155179.

20. KOSICKA-GĘBSKA M., GĘBSKI J., 2008, Żywność zmodyfikowana genetycznie-bariery i możliwości rozwoju w opinii respondentów, in: Roczniki $\mathrm{Na}$ ukowe Stowarzyszenia Ekonomistów Rolnictwa $i$ Agrobiznesu, 10(1), p. 182-185.

21. KUNDZEWICZ Z. W., JUDA-REZLER K., 2010, Zagrożenia związane ze zmianami klimatu, in: $\mathrm{Na}$ uka, 4, p. 69-76.

22. MALEPSZY S., 2006, Uwagi o wprowadzeniu do rolnictwa w Polsce odmian genetycznie zmodyfikowanych, in: Postępy Nauk Rolniczych, 6, p. 3-15.

23. MALEPSZY S., ORLIKOWSKA T., ORCZYK W., MAJEWSKA-SAWKA A., 2009, Rośliny genetycznie zmodyfikowane., in: Biotechnologia roślin, ed. Malepszy S., PWN, Warszawa, p. 455-544.

24. MORGAN R. P., RICKSON R. J., 2003, Slope stabilization and erosion control: a bioengineering approach, Taylor \& Francis.

25. MOSTAFAVI A., SHAMSPUR T. 2009. Application of modified multiwalled carbon nanotubes as a sorbent for simultaneous separation and preconcentration trace amounts of Au (III) and Mn (II), in: Journal of Hazardous Materials, 168(2-30), p. 15481553.

26. NIEMROWICZ-SZCZYTT K., BARTOSZEWSKI G., GNIEWOSZ M., ORCZYK W., ZWIERZCHOWSI L., 2012, GMO w świetle najnowszych badań. Doskonalenie organizmów na potrzeby człowieka, Wydawnictwo SGGW, Warsaw.

27. ONG H. G., LI B., CAO X., CHEAH J. W., ZHOU X., YIN Z., LI H., WANG J., BOEY F., HUANG W., ZHANG H., 2010, All-Carbon Electronic Devices Fabricated by Directly Grown Single Walled Carbon Nanotubes on Reduced Graphene Oxide Electrodes, Wiley Online Library.

28. POSKROBKO B., 2011, Ekonomia zrównoważonego rozwoju $w$ świetle kanonów nauki, Wydawnictwo WSE w Białymstoku, Białystok.

29. PRZYBECKI Z., PAWEŁKOWICZ M. WÓYCICKI R., 2010, Sekwencjonowanie genomów i rozwój biotechnologii. Prace przeglądowe, in: Biotechnologia, 4 (91), p. 9-23.

30. ROBERTSON F., SAMY M., 2015, Factors affecting the diffusion of integrated reporting - A UK FTSE 100 perspective. Sustainability Accounting, in: Management and Policy Journal, 6(2).

31. SAVAGE, N., DIALLO, M. S., 2005, Nanomaterials and water purification: opportunities and challenges, in: Journal of Nanoparticle Research, 7(4-5), p. 331342.

32. SKOWROŃSKI A., 2006, Zrównoważony rozwój perspektywą dalszego postępu cywilizacyjnego, in: Problemy Ekorozwoju/ Problems of Sustainable Development, 1(2), p. 47-57.

33. SMITH L. H., KITANIDIS P. K., MCCARTY P. L., 1997, Numerical modeling and uncertainties in rate coefficients for methane utilization and TCE come- 
tabolism by a methane-oxidizing mixed culture, in: Biotechnology and Bioengineering, 53(3), p. 320331.

34. SRIVASTAVA A., SRIVASTAVA O. N., TALAPATRA S., VAJTAI R., AJAYAN P. M., 2004, Carbon nanotube filters, in: Nature Materials, 3, p. 610614.

35. TWARDOWSK, T. , WĘGLEŃSKI P., 2012, The official position of the Biotechnology Committee of the Polish Academy of Sciences on the commercial use of GMOs. New technologies as an opportunity for the Polish economy: GMOs for industry and agriculture, in: BioTechnologia.
36. WANG X., WAJE M., YAN Y., 2005, CNT-based electrodes with high efficiency for PEMFCs, in: Electrochemical and Solid-State Letters, 8(1), p. 42-44.

37. WANG L. K., TAY J. H., TAY S. T. L., HUNG Y. T., 2010, Environmental Bioengineering, 11, Springer.

38. WARACZEWSKA Z., NIEWIADOMSKA A., GRZYB A., 2018, Wybrane metody bioremediacji in situ z wykorzystaniem mikroorganizmów. Woda-Środowisko-Obszary Wiejskie, Falenty.

39. WÓJCIK P., TOMASZOWSKA B., 2005, Biotechnologia w remediacji zanieczyszczeń organicznych. Prace przeglądowe, in: Biotechnologia, 4(71), p. 156172. 
